\title{
Fallopian Tube Cancer pTX TNM Finding v7
}

National Cancer Institute

\section{Source}

National Cancer Institute. Fallopian Tube CancerpTX TNM Finding v7. NCI Thesaurus.

Code C89667.

Fallopian tube cancer in which the primary tumor cannot be assessed. (from AJCC 7th Ed.) 